the valley of the Lower Thames, and that these deposits were laid down from Clactonian 2/Acheulian times onwards.

30 Southwick Street, Hyde Park, W.2.

Hodges, Ono Houso Lano,

J. P. T. Burchelt. Tpswich.

\section{Confirmation of the Space-Group of Epsomite}

AцтнолGн orthorhombic magnesium sulphate heptahydrate (epsomite) has been the subject of two previous investigations, ${ }^{1,2}$ in neither case was a complete structure proposed. We commenced work on this substance in the hope of carrying the knowledge of its structure to a more complete stage. Due to unforeseen circumstances, however, the investigation has been interrupted, and it is uncertain when the study can be resumed. We have considered it of interest to report some of our results, since they agree with those already in tho literature, and thus serve as a third check on the dimensions of the unit, cell and on the space-group.

The crystals employed were small prisms having faces of the form $\{110\}$ prominently developed. The apparatus consisted of a Shearer $\mathrm{X}$-ray tube fitted with a copper target $\left(K_{\alpha}=1.54\right.$ A. $)$ and a Müller spectrograph.

The results obtained for the size of the unit cell and the number of molecules per cell compared with the data of Cardoso and of Westenbrink are as follows :

\begin{tabular}{|c|c|c|c|}
\hline & $\begin{array}{c}\text { Barnes and } \\
\text { Hunler. }\end{array}$ & Cardoso. & Westenbrink. \\
\hline$a_{0}$ & $11 \cdot 94$ & $11 \cdot 91$ & $11 \cdot 89$ \\
$b_{0}$ & $12 \cdot 03$ & $12 \cdot 02$ & $12 \cdot 01$ \\
$c_{0}$ & $6 \cdot 86_{5}$ & $6 \cdot 87$ & $6 \cdot 86$ \\
mol./cell & 4 & 4 & 4 \\
\hline
\end{tabular}

Oscillation photographs showed conclusively that $\{h 00\},\{0 k 0\}$, and $\{00 l\}$ are halved. This was based on the fact that reflections from the odd orders from 1 to 12 , inclusive, for $\{h 00\}$ and $\{0 k 0\}$, and from 1 to 6 , inclusive, for $\{00 l\}$ were missing. Higher orders than these were unattainable with the apparatus employed.

The only orthorhombic space-group with these halvings ${ }^{3}$ is $Q^{4}$, which is that found by Cardoso and by Westenbrink. Since $Q^{4}$ is in the bisphenoidal class, the X-ray data lead to the same conclusion as to crystal class as that reached by the methods of crystallography.

Our results for the dimensions of the unit cell agree more closely with those found by Cardoso, which are those selected by Wyckoff for quotation in the second edition of the "Structure of Crystals". They were obtained experimentally from rotation photographs about each of the three axes. Westenbrink calculated the primitive translations along the $a$ and $c$ axes by assuming the erystallographic axial ratio $(a: b: \mathrm{c}=$ $0.9901: 1: 0.5709)$ \& to be correct and measuring $\theta / 2$ accurately for the second order reflection from $\{110\}$.

This work was carried out during the tenure by one of us (R. G. H.) of a bursary from the National Research Council of Canuda.

WILLIAM H. BARNES.

R. G. Hunter.

Departments of Chemistry and of Physies, MeGill University, Montreal, May 31 .

1 Cardoso, Z. Krist., 63, 19; 1926.

2 Westenbrink, Proc Acrd 'Sci, Amsterdam, 29, 1223; 1926.

3 Westenbrink, Proc. Acsd. Sci. Amsterdam, 29, 1223; 1926.

" Astbury and Yardley, Trans. Roy. Soc, A, 224, 230-236; 1924

No. 3272, VoL, 130]
An X-Ray Study of Mannitol, Dulcitol, and Mannose

IN connexion with a paper under the above title, ${ }^{1}$ Prof. W. N. Haworth has pointed out that the actual space formulæ of d-mannitol and i-dulcitol are :

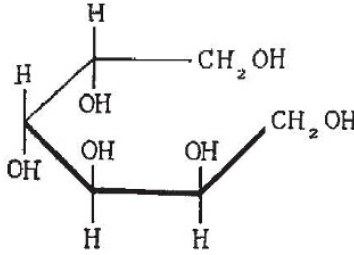

d-Mannitol.

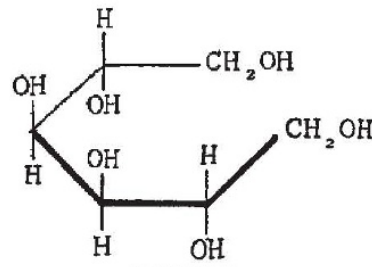

i-Dulcitol.
On uncoiling these to give zigzag or slightly spiral chains of the nature suggested by the dimensions of the unit cells, the projections of the chains on a plane perpendicular to the plane of the zigzag become

$$
\begin{aligned}
& \mathrm{OH} \mathrm{H} \mathrm{HOH} \quad 0 \mathrm{H} \mathrm{OH} \mathrm{H} \mathrm{H} \\
& \begin{array}{cc}
\mathrm{HO} \cdot \mathrm{CH}_{2}-\mathrm{C} \\
\mathrm{H} \text { OH OH H } \\
\text { d-Mannitol. }
\end{array}
\end{aligned}
$$

This involves the alteration in position of two hydroxyl groups per molecule in the models illustrated in the paper. These alterations do not affect materially the fundamental features of the respective unit cells, but they introduce interesting possibilities which will be discussed in a separate paper.

I am very much indebted to Prof. Haworth for this correction. Thora C. Marwick.

Textile Physics Laboratory,

The University, Leeds, June 15.

1 Proc Roy. Soc., A, 131, 621; 1931.

\section{Removal of Added Nitrogen from Grassland Soils}

Work has been in progress in these laboratories since 1929 on the available nitrogen of grassland soils, with especial reference to the soil ammonia, which in these soils preponderates in quantity and possibly also in importance over the nitrate. The work as a whole will not be completed for some time, but information has already been obtained which may be useful to other workers on the nitrogenous manuring of grassland.

An outstanding result is the spced with which nitrogen added to grassland soils, whether as ammonia or as nitrate, is removed. Observations made here and elsewhere on the rapid falling-off in the response to a single dressing of nitrogen on repeatedly mown plots have suggested that the added nitrogen could not remain for long in the soil, but its rate of removal by vigorously growing herbage has proved unexpectedly high.

A convenient measure of rate of removal is the interval required for three-quarters of the added nitrogen to disappear from the soil. With an early spring application (Feb. 18, 1930) of sulphate of ammonia on pasture, this interval was throe weeks, and about the same time was reguired for a late autumn dressing (Dec. 6, 1929) ; theso dressings were applied when the plant was probably almost dormant. For a heavy dressing of sulphate of ammonia applied in mid-spring, when vigorous growth was beginning, the interval required for disappearance of threefourths of the added nitrogen was only seven days (Park Grass, meadow hay, $3_{3}^{2}$ ewt. sulphate of ammonia per acre applied March 27, 1931). In late 